Revue de l'Institut des langues et cultures

d'Europe, Amérique, Afrique, Asie et Australie

$40 \mid 2020$

English for Specific Purposes (ESP) and the Underlying Dynamics of Power, Empowerment and Disempowerment

\title{
English as an Empowering Lingua Franca in the French Workplace: A Case Study of Language Competence in Job Performance
}

Du savoir-dire au pouvoir-faire: étude de l'anglais comme lingua franca dans les milieux professionnels français

\section{Philippe Millot}

\section{(2) OpenEdition}

\section{Electronic version}

URL: http://journals.openedition.org/ilcea/10651

DOI: 10.4000/ilcea.10651

ISSN: 2101-0609

\section{Publisher}

UGA Éditions/Université Grenoble Alpes

\section{Printed version}

ISBN: 978-2-37747-204-8

ISSN: 1639-6073

\section{Electronic reference}

Philippe Millot, «English as an Empowering Lingua Franca in the French Workplace: A Case Study of Language Competence in Job Performance », ILCEA [Online], 40 | 2020, Online since 04 June 2020, connection on 05 September 2020. URL : http://journals.openedition.org/ilcea/10651 ; DOI : https:// doi.org/10.4000/ilcea.10651

This text was automatically generated on 5 September 2020.

(C) ILCEA 


\title{
English as an Empowering Lingua Franca in the French Workplace: A Case Study of Language Competence in Job Performance
}

\author{
Du savoir-dire au pouvoir-faire: étude de l'anglais comme lingua franca dans \\ les milieux professionnels français
}

Philippe Millot

\section{Introduction}

1 When one looks at the considerable body of literature on the emergence of English as a Lingua Franca (ELF)-from the first descriptions of World Englishes going back to the early 1970s (Quirk, Greenbaum, Leech \& Svartvik, 1972) to more recent ones in which ELF has gained a more established status whether in business, academic or everyday situations-one is struck by the ideological slant found in many linguistic analyses. Studies describe the asymmetrical relationships which in many cases lead to what authors conceive of as the "unfair" treatment of nonnative speakers regarding unattainable native or near-native expectations of language competency:

Ministries of Education, and even Council of Europe conferences, have on occasions set as a goal for the learning of English as a foreign language the acquisition of 'native' or 'near native' proficiency; that is to say, they have expected learners of English as a foreign language (in no more than three or four lessons a week and only during term time) to become quite, or almost, as fluent and 'correct' in their use of an alien tongue as those who have acquired that proficiency from infancy; who as young children have devoted the major part of their waking hours to absorbing the language; and who have, as school children and as adults, consciously and unconsciously, made a complex prosody and countless allusions and idiomatic expressions into integral features of their own speech. (Close, 1981) 
2 The literature-past and present-resonates with the many personal stories of scientists being refused access to prestigious international journals on the grounds that their style does not conform to the native norm or those of professionals losing command during meetings as they struggle to make their point during rapid, complex, high-stake exchanges with native speakers. In an article in the Huffington Post (21 June 2013), Jérôme Saulière, a French specialist in management science, provides a vivid description of such occurrences:

Lors des réunions, les salariés les moins à l'aise en anglais profitent des basculements vers le français comme de «fenêtres de tir ", tandis que les autres les accusent de ne pas respecter leur collègue étranger... Les premiers rétorquent que les seconds veulent les "perdre" volontairement en haussant le registre de la langue. La maitrise de l'anglais devient alors une nouvelle forme de pouvoir, audelà de l'expertise et de la position hiérarchique.

["During meetings, professionals who suffer from a language deficit in English exploit language shifts towards French as windows of opportunity. But other colleagues then accuse them of not respecting their foreign colleague... The former retort that the latter seek deliberately to confuse them by raising the language registers. The command of English thus becomes a new form of power beyond that of expertise and hierarchic status." (Our translation)]

3 Such accounts illustrate the well-documented fact that use of language easily disempowers those who do not share the local norm and, conversely, empowers the "owners of the norm". In the case of English, the "owners" equates with what Kachru (1981) described as the "inner circle" of users which comprises people who live in countries (e.g. the UK, the USA, Australia) where English is the official language and whose users are considered native speakers. However, equating native English with competence and power is an erroneous oversimplification in a globalized world. As Jenkins (2007) showed in her study of the international university, being a native speaker may also be a source of disempowerment when the latter is in multilingual contexts in which nonnative speakers feel perfectly comfortable and legitimate. According to Jenkins and other scholars in the field such as Seidlhofer (2011), the feeling of legitimacy is based on the fact that ELF speakers are not mere users of a language but, on the contrary, have appropriated the linguistic resources and acquired a sort of "ELF identity" which expands far beyond the native/nonnative dichotomy and resides in a set of innovations identified through corpus-driven analyses (Cogo \& Dewey, 2012) and ethnographically highlighted cases of successful communicative strategies (Knapp \& Meierkord, 2002).

4 The language experience of French professionals clearly fits into this contrasted picture of empowerment and disempowerment. Although the native model remains ideologically strong in France, many professionals admit that "their English", although it may not conform to the native norm, is an empowering tool, enabling them to both enter the job market and perform their jobs. Many stakeholders and scholars agree on this well-documented reality ${ }^{1}$ but the use of English by French professionals has received relatively little scholarly attention except for Isani's cultural competence framework (2004), Wozniak's ethnographic study of French mountain guides (2010), or Millot's case study of BELF emails in the French corporate world (2017). Although these studies provide valuable information about how competence in business English may be conceptualized, the concept of language competence in French business settings 
remains largely unexplored. The business world's silence on the issue is also worth considering. For example, what Reeves and Wright, two specialists in international management, observed in the mid-1990s still applies to a large extent when they note that the "use of language and the effectiveness of communication within organizations and between organizations is rarely scrutinized" (1996: 26). They also remark that English, and international languages in general, are often seen as "a second nature" by the stakeholders themselves, with professionals considering English as a "taken for granted" part of professional competence (ibid.).

Conversely, research into workplace and professional discourse has widely developed in international discourse studies (Candlin, 2002; Koester, 2010, Candlin \& Sarangi, 2017). The studies clearly indicate that identifying the nature and the structure of competence in English in business or professional contexts requires the consideration of several discursive parameters such as, for example, genre, register or phraseology. They also suggest that language competence is largely defined by what people do at work, i.e. their job performance, as illustrated by Bhatia (2002) whose model of professional discourse is closely linked to professional knowledge.

6 This article seeks to explore this articulation in the French business context. More particularly, we look at how a sampling of the professional world considers Business English as a Lingua Franca (BELF) competence at work through three complementary methods: a corpus analysis of French job advertisements in which we look at how competence in English is typically presented to job seekers, an online survey in which professionals are asked to describe the function of English in their jobs, and finally, a set of interviews of professionals (employees as well as recruiters) in which we investigate their personal view of competence in English.

\section{Theoretical framework}

\subsection{Defining professional competence from management and ethnographic perspectives}

7 An early definition of professional competence is based on Taylor's well-known principles according to which job-related tasks may be systematically regulated by management by using scientific rules to maximize work efficiency (Taylor, 1911). Taylor's approach to competence has progressively been replaced by other, more holistic ones (Boyatzis, 1982; Attewell, 1990; Sandberg, 2000, 2001; Zarifian, 2004; Sandberg \& Pinnington, 2009) in which jobs are no longer defined as sets of regulated actions and procedures but as specific situations involving relations between a person and a professional situation. Boyatzis' distinction between "competencies", defined as the "underlying characteristics" required to do a job, and "skills" as abilities to "demonstrate a system and sequence of behavior that are functionally related to attaining a performance goal" (1982: 33), show that competence should be considered as a global model involving a very broad range of characteristics such as personal abilities, field knowledge, personality, self-image which, according to the author, "may or may not be known to the person" (ibid.).

Some recent studies also suggest that professional competence in work performance is no longer just a job-oriented concept but also a person-oriented one (Sandberg, 2001; Rouleau \& Balogun, 2011). For example, Sandberg (2001) shows that skills and 
competencies should not be considered as entities separate from the person, as in the case of Taylor's workers who acquire better skills and increase their performance, but be considered as resulting from the person's own conception of the job. According to the author, "human competence is not primarily a specific set of attributes. Instead, workers' knowledge, skills, and other attributes used in accomplishing work are preceded by and based upon their conceptions of work" (Sandberg, 2001: 20). This person-oriented view of competence is echoed by French organizational sociologist Zarifian who defines professional competence as a person's ability to decide on "what to do when no longer told what to do"2 (2004: 45). However, as Wenger's study of communities of practice suggests, "we are who we are by negotiating local ways of belonging to broader constellations and of manifesting broader styles and discourses" (1998: 149). This suggests that defining professional competence lies not only in the identification of individual abilities and conceptions of work, but also, on collective abilities and conceptions which contribute to the identity of professional communities. The relation between individual and collective abilities and conceptions imply that developing competence should not be based on improving competencies and skills per se but, rather, on improving people's abilities as well as their own conceptions of these towards those that are valued by the professional community to which they belong.

9 These findings from the management literature somewhat echo the ethnographical studies which developed in the 1990s and early 2000s (Drew \& Heritage, 1992; Sarangi \& Roberts, 1999; Jacoby \& McNamara, 1999) in which professional competence is largely perceived as a process in which specialized knowledge and practice are learnt through interaction within the professional setting (e.g. co-workers, settings, activities). As Jacoby and McNamara claim:

The development of professional competence is but a specialized form of socialization, a general social and interactional process long recognized as the vehicle through which culturally specific knowledge, language discourse, cognition, skills and practice are transmitted and developed. (1999: 224)

\subsection{Shaping BELF competence through the concept of situation}

10 The BELF conceptual framework is mostly drawn from the English as a Lingua Franca (ELF) model based on the observation that English as a native language (ENL), especially in continental Europe, is no longer a goal in itself but an adjunct to the primary function of communication between speakers of other languages than English (Jenkins, 2007; Seidlhofer, 2011). The global norm has been identified through various features such as consistent, phonological differences from the native varieties (Jenkins, 2007), new lexicon stemming from international institutions especially in Europe (Jenkins, Modiano \& Seidlhofer, 2001), innovations in the lexico-grammatical field (Cogo \& Dewey, 2012), as well as in pragmatic competence (House, 2012). BELF may be considered as a sub-variety of ELF which is typically defined as a "neutral code that is shared among the members of the international business community for the function of working in multinational companies and doing business" (Louhiala-Salminen \& Kankaaranta, 2012: 264). Most studies actually show that ELF is typically used in highly specialized contexts such as wine-making (Poncini, 2005), or among technicians and engineers who use the variety to share technical information and solve problems. As a consequence, BELF competence is first and foremost specialized in that it enables 
language users to fully deal with the complexity of professional situations which, according to Candlin and Sarangi (2017), comprise many aspects such as "specialized knowledge", "corporate organization", "power, authority" and even "ethics". The concept of situation, therefore, appears as a critical one for the shaping of BELF competence.

11 Halliday and Hasan define "situations" as "extra-linguistic factors which have some bearing on the text itself" (1976:21). The factors are organized in three broad categories, namely "field" defined as "the total event in which the text is functioning together with the purpose of the activity", "mode" defined as the "function of the text in the event" (both spoken or written channels and genres), and "tenor" defined as "the type of role interaction, the set of relevant, social relations permanent or temporary, among the participants involved" (ibid.: 22). This functional framework provides insights into all kinds of communicative situations and is also particularly relevant in the context of global communication.

In this context, the "field" parameter may be defined as a set of elements showing the professionals' knowledge in a particular subject area. As Bhatia suggests, expert knowledge of professionals is "the cumulative result of their long experience and/or training within the specialist community" (1993: 14). He also suggests that this form of knowledge tends to structure communication in ways which are specific to professional communities. More particularly in BELF, the "field" facet of competence implies the professionals' ability to share common expert knowledge in order to achieve joint actions even if linguistic realizations do not necessarily comply with the native norm (Shaw, 2011; Louhiala-Salminen \& Kankaanranta, 2012).

The "tenor" parameter of competence in BELF may be defined as the workers' ability to develop and maintain global relationships on various channels. One salient and widely described feature of this part of competence is the professionals' ability to deal with intercultural communication, e.g. using appropriate forms of politeness either in the shared language or in the participants' languages.

Lastly, research into workplace communication in global settings (Bargiela-Chiappini \& Nickerson,1997; Gimenez, 2006; Poppi, 2016) has provided ample evidence that competence in global professional networks implies the professionals' ability to work on various communication modes and channels. More particularly, Nordic ELF studies (Nickerson, 2000; Louhiala-Salminen, 2002; Kankaanranta, 2006) show the importance of workers' ability to deal with discursive sequences including email, telephone, and face-to-face conversations with business partners who may not necessarily share the same linguistic and cultural backgrounds.

\subsection{Conclusions drawn}

Professional competence and BELF competence are to a great extent linked. Both have developed into overarching concepts reaching beyond functional abilities (the ability to perform a task, the ability to write an email, and so on) into a set of situation-based competencies including what people perform but, also, how they perceive their own performance or, in other terms, their ethics. These performances and conceptions are not necessarily idiosyncratic since professional communities on the one hand, and BELF users on the other, naturally share many internal characteristics and purposes. 
16 Although most studies have focused on the characterization of "objective data" such as the discourses that emerge from business situations, competencies in English may also be explored through "subjective data" since professional and language competence are largely based on perceptions or attitudes leading to a great deal of adaptive behavior according to the business or professional situation in which the participants are involved. Since little is known about the latter perspective, the following sections focus on what is perceived and thereby what is expected as competent language behavior in English in the global workplace through the case of the French current job market.

\section{Method}

17 Just as some studies focus on BELF competence in Northern European countries such as Finland or The Netherlands (Kankaanranta \& Planken, 2010), our study explores a similar topic in quite a different regional, cultural and linguistic area, namely France. Our method seeks to identify the notion of "competence in English among French professionals and managers". The identification was carried out from three perspectives, namely by examining a small corpus of job advertisements in order to define the French job market's general expectations, by conducting an online survey giving respondents the opportunity to list and briefly describe the BELF parts of their jobs, and by conducting semi-guided interviews in which we asked professionals, including HR professionals, to describe their own view of BELF competence.

\subsection{Job advertisements corpus}

18 Job advertisement analysis has already been the focus of scholarly attention by Weeks (1974) who studied writing skills expectations across 600 jobs advertisements, and Arnold who studied "the communication competencies listed in job descriptions in the National Employment Weekly, a publication of the Wall Street Journal" (1992: 15). Our own small corpus of French job advertisements consists of 300 classified ads from major groups 1 and 2 as defined by the International Standard Classification of Occupations (ISCO-08). As shown in Table 1, each group covers a broad range of occupations which may be considered as "highly globalized" in the sense that English has now become a requirement in the hiring process. The job advertisements were chosen randomly over a two-week period in May 2017 by using both governmental and private sources. The governmental source was the website of the official French employment agency (Pôle Emploi) and the private source was the job agency Monster ${ }^{3}$. Table 1 shows that most job advertisements concern the Professionals category $(n=233)$, the Managers category representing fewer cases $(n=67)$, a difference which may be explained by the fact that the number of managers in most companies is traditionally much lower than that of Professionals. Although the corpus may provide interesting insights into language competence expectations of the business world, it is worth noting that job ads in France only provide a partial view of job offers since unsolicited applications and informal contacts represent the majority of overall recruitment methods in this country (respectively $45 \%$ and $25 \%$ ), according to the LEMP report (2015). 
Table 1. - Distribution of job advertisements by ISCO-08 categories.

\begin{tabular}{|l|l|l|}
\hline ISCO code & Occupational category & Job ads (n) \\
\hline 12 & Administrative and commercial managers & 20 \\
13 & Production and specialized services managers & 47 \\
21 & Science and engineering professionals & 53 \\
22 & Health professionals & 50 \\
25 & Information and communication technology professionals & 100 \\
26 & Legal, social and cultural professionals & 30 \\
\hline Total & & 300 \\
\hline
\end{tabular}

\subsection{Online survey of views of competence in English in the French workplace}

19 Our online survey is based on a questionnaire which seeks to provide a broad picture of professionals' own conceptions of what it is to be competent in English in the French workplace. The questionnaire was submitted in 2017 via the socio-professional network LinkedIn to 55 professionals from the three previously mentioned business environments (i.e. industry, business administration, communication and information systems) and from various other professional domains such as engineering, finance management, HR management, communication management or computing. The professionals surveyed represent an educated sample with either Master's $(78 \%)$ or Bachelor's (22\%) degrees. The majority are between 35 and 50 years old (65.5\%), those younger (between 18 and 34 years old), older (above 50 years old) being a minority (respectively 9.1\% and 25.5\%).

On the one hand the survey sought to identify professional situations in English which professionals consider as "recurrent" or "important". As explained earlier, professional situations were identified according to three parameters (field, mode and tenor), which enabled us to cover a fairly wide range of organizational genres such as emails, meetings, technical reports or negotiations, and interlocutor types such as native and non-native speakers. On the other hand, the survey sought to identify skills and qualities considered as necessary for successful communication and the realization of the identified situations. The questions were asked either directly with items such as "how useful is English for doing your job?" or indirectly with an item asking the professionals surveyed to describe the ideal form of training in English. Lastly, the survey asked professionals whether and how their English was tested during the recruitment process.

\subsection{Interviews of French users of English and recruitment professionals}

21 As a complementary, qualitative approach to the characterization of competence of English in the French workplace, we adopted a phenomenographic approach ${ }^{4}$ (Sandberg, 2000) which consisted in conducting short, semi-guided interviews in which we sought to identify people's conceptions of English in the workplace such as, for 
example, how they defined the notion, as well as what they particularly valued. To identify the relationships between overall job performance and competence in English, we asked them to describe what skills or qualities were important in their jobs and what skills or qualities were necessary in English. We also asked peripheral questions to ensure we correctly understood what the professionals meant in their answers (i.e. asking them to give examples or anecdotes). The interviews were conducted between 2015 and 2017 with two groups of participants, five "users" of English as a working language on the one hand and, on the other, six "recruitment professionals". The "users" group covers the three previously identified business environments (industry, business administration, and communication and information management) as well as several domains such as electronics engineering, computer network engineering, sales management and finance management. The "recruitment professionals" group includes five HR managers from multinational companies of different sizes and from different business environments. The group also includes one manager who works at Pôle Emploi (the French public job centre). The interviews of the user group focused mostly on the way the participants perceived their own needs in English in their professional lives and how they personally coped with them. We asked them factual questions about the kinds of communicative situations they were involved in and we also asked them to give examples of coping strategies. Interviews of the "recruitment professionals" focused on the importance they gave to English skills in recruitment and on their own experience as "testers" of English in the hiring process. As with the first group of interviewees, we asked them to provide anecdotes and examples of how candidates typically behaved and, more generally, to present their own view of what it is to be "competent in English" in the French workplace.

\section{Results}

\subsection{Job advertisements}

The analysis of our job ads corpus shows that English as a professional competency is formally mentioned in only $30 \%$ of job advertisements, thus leaving the vast majority of job advertisements without any reference to the competency (see Table 2). When it was used, the word "English" typically occurred alongside qualities which refer to various kinds of proficiency levels ${ }^{5}$ (11\% of job advertisements), or applied domains ${ }^{6}$ ( $2 \%$ of job advertisements) thus reinforcing its centrality in the job requirements. The word "English" was particularly frequent in the "science and engineering professionals" subcorpus (72\% of advertisements) and was regularly associated with words referring to "proficient" levels ( $42 \%$ of advertisements). Formal mentions of basic requirements in English were rarely found in the corpus (1\%).

Table 2. - Distribution of English competence markers according to job types.

\begin{tabular}{|l|l|l|l|l|l|l|l|l|}
\hline ISCO Code & \multicolumn{2}{|l|}{ English } & \multicolumn{2}{|c|}{ Proficiency } & \multicolumn{2}{|c|}{ Specialised } & \multicolumn{2}{|c|}{ Basic } \\
\hline & $\mathbf{n}$ & $\mathbf{\%}$ & $\mathbf{n}$ & $\mathbf{\%}$ & $\mathbf{n}$ & $\mathbf{\%}$ & $\mathbf{n}$ & $\mathbf{\%}$ \\
\hline
\end{tabular}




\begin{tabular}{|l|l|l|l|l|l|l|l|l|}
\hline 12 & 6 & 30 & 4 & 20 & 1 & 5 & 1 & 5 \\
13 & 11 & 23 & 5 & 11 & 1 & 2 & 0 & 0 \\
21 & 38 & 72 & 24 & 45 & 4 & 7 & 0 & 0 \\
24 & 12 & 24 & 9 & 18 & 0 & 0 & 1 & 2 \\
25 & 33 & 33 & 22 & 22 & 1 & 1 & 0 & 0 \\
26 & 1 & 3 & 1 & 3 & 0 & 0 & 0 & 0 \\
\hline Total/average & 101 & 30 & 65 & 20 & 7 & 2 & 2 & 1 \\
\hline
\end{tabular}

12 Administrative and commercial managers; 13 Production and specialized services managers; 21 Science and engineering professionals; 24 Business and administration professionals; 25 Information and communications technology professionals; 26 Legal, social and cultural professionals.

23 Beyond the explicit mentions of the word "English" in job advertisements, some indicators may involve implicit demands for competence in English. Among these indicators, one may include the type of company (international companies vs local ones), the type of market (international vs local) or the professional domains which, in some cases, may almost exclusively be documented in English (e.g. engineering). These indicators were found in job advertisements which, although they did not mention "English" as a requirement, featured tell-tale elements such as "working in an international environment" or "our world-wide clients" which most probably involved some form of contact with English. The job ad below shows the case of an industrial company seeking an accountant who will be working in "an international context" and at the "financial, relational and customs levels for both export and France".

Example 1. - Job advertisement featuring implicit requirements for English through the reference to an international market and to export:

$\mathrm{Au}$ sein du service de la Direction Administrative et Financière et rattaché au Responsable Clients, vos missions sont : Assurer dans un contexte international, la gestion administrative des comptes clients, au niveau financier, relationnel et douanier pour l'export et la France.

[Working in an international context under the Client Manager for the Administration and Finance Department, you will be in charge of the administrative management of customer accounts, at financial, relational and customs levels, for export and domestic operations. (Our translation)]

Other typical cases included jobs in multinational companies (MNCs) which were set in centralized corporate activities such as accounting, finance or information management and which therefore implicitly involved some form of central-level, intersubsidiary communication. Example 2 shows the case of a job advertisement in which the company's description strongly suggests some form of inter-subsidiary communication, thereby entailing the use of BELF.

Example 2. - Job advertisement extract featuring implicit requirements for English for a central function at Orona, an MNC with its headquarters in Spain which specializes in "the design, manufacture, installation, maintenance, and modernisation of elevators, escalators, moving ramps and walkways". ${ }^{7}$

We are seeking an administrative coordinator. The candidate will be involved in the following jobs: dealing with in-coming calls, administrative record management, specific, administrative document making [...].

Our analysis of job advertisements also revealed that English tends to be used alongside other languages. A total of nine languages other than English or French were found in 
our small corpus, namely Arabic, Chinese, German, Hindi, Italian, Japanese, Spanish, Persian, Portuguese and Russian.

\subsection{Online survey}

Our survey seeks to present a very general portrait of BELF competence in the French workplace as perceived by the respondents themselves. The results confirm the previous studies to a great extent, more particularly the general fact that English is becoming a European lingua franca in Northern countries as well as in Southern ones such as France. Our survey results also present the "global users of English", i.e. the professionals who are particularly exposed to English in their day-to-day activities and who are equally aware of what constitutes BELF competence. Compared with other respondent categories where English is presented as a less central option in the job competence framework, the global users tend to include many features including "intercultural skills", "knowledge of the English-speaking world" or "terminology and professional jargon".

The online survey results enabled us to identify two correlations which appear to play a role in the definition of BELF competence in the French workplace. A first correlation was found between feeling at ease or comfortable in English and the type of institution and the degree of usefulness of the language in the overall job (see Table 3). Our results show that the respondents who claim to feel at ease (category 3) or slightly less at ease (category 2) in English tend to work in MNCs and have jobs in which English is generally considered as "indispensable". Conversely, the respondents who claim to be "much less at ease" (category 1), tend to work either for the public administration or for local companies and tend to have jobs in which English is generally considered as only "useful" or "quite useful". However, contrary to what might have been expected, no correlation was found between the degree of ease and the interlocutors' status regarding English (L1 or L2). All three categories are involved in exchanges with natives and non-natives in more or less equal proportions. This tends to show that BELF is not necessarily perceived as an easier or a "basic" variety of English compared with "native Business English" but, rather, that it is considered as a variety with issues of its own.

Table 3. - Perception of comfort level in English among the surveyed professionals.

\begin{tabular}{|l|l|c|c|}
\hline Category & General perception & $\mathrm{n}$ & $\%$ \\
\hline 1 & Much less at ease than in French & 27 & 48 \\
2 & Slightly less at ease than in French & 17 & 30 \\
3 & As at ease as in French & 12 & 21 \\
\hline & Total & 56 & 100 \\
\hline
\end{tabular}

The second correlation concerns the link between how the respondents perceived the importance of English in their jobs and the required level of language. As Table 4 shows, the respondents who feel that English is "indispensable" in their jobs tend to consider the required level as "high". On the other hand, those who perceive that English is "quite useless" tend to consider that requirement as "basic". 
Table 4. - Perception of the required English level according to degree of usefulness in the job.

\begin{tabular}{|l|l|l|l|l|l|l|}
\hline & \multicolumn{2}{|c|}{ High level } & \multicolumn{2}{c|}{ Average level } & \multicolumn{2}{c|}{ Basic level } \\
\hline & $\mathbf{n}$ & $\mathbf{\%}$ & $\mathbf{n}$ & $\mathbf{\%}$ & $\mathbf{n}$ & $\mathbf{\%}$ \\
\hline Indispensable & 18 & 60 & 10 & 33 & 2 & 7 \\
Useful & 3 & 20 & 11 & 73 & 1 & 7 \\
Quite useless & 0 & 0 & 2 & 18 & 9 & 82 \\
\hline
\end{tabular}

According to our results, the correlation between how useful English is in day-to-day activities and the perceived required level depends on the variety of business genres which the respondents are confronted with. In the "indispensable" category, this variety is particularly high in that all typical business genres (email, telephoning, meetings, conference calls, technical reports, problem solving, and so on) are mentioned as being recurrent, contrary to the "quite useless" or the "useful" categories where the number of genres is limited to only a few such as "writing emails" or "reading technical documents". The correlation between the degree of usefulness and the required level is also related to the number of other skills and knowledge which are considered necessary. Although knowledge of "terminology and technical jargon" can be found in all three categories, other forms of knowledge such as "intercultural skills", "knowledge of the English-speaking world" or "general grammar and vocabulary" tend to accumulate in the "indispensable" category and are scarcer in the "useful" and "quite useless" categories.

When asked about how comfortable they feel when using English (cf. Table 5), the majority of our respondents admit they are either much less at ease than when they use French (51\%) or simply less so (28\%). However, a significant number of respondents admit they feel "as at ease as when they use French". Counter-intuitive results were found when the data regarding the degree of ease were compared with those regarding the status of English among participants. Although we expected the respondents to feel more comfortable with their L2 counterparts, we found that a surprisingly large majority felt uncomfortable when communicating in Lingua Franca situations. According to the survey results and when asked in which situations they felt "uncomfortable", most respondents admitted that oral conversations, especially on the phone with other interlocutors with nonnative accents, are generally problematic in that they require "a warm-up" period to get used to the accents. Another typical, problematic situation mentioned by the participants relates to the social and emotional dimensions of English at work such as using the language under stress or pressure, or doing humor to establish or develop professional contacts.

Table 5. - Perceived degree of comfort in English according to status of English of interlocutors.

\begin{tabular}{|l|l|l|l|r|l|l|l|l|}
\hline & \multicolumn{2}{|c|}{ As comfortable } & \multicolumn{2}{|c|}{ Less comfortable } & \multicolumn{2}{|c|}{ Much less comfortable } & \multicolumn{2}{|c|}{ Total } \\
\hline & $\mathbf{n}$ & $\mathbf{\%}$ & $\mathbf{n}$ & $\mathbf{\%}$ & $\mathbf{n}$ & $\mathbf{\%}$ & $\mathbf{n}$ & $\mathbf{\%}$ \\
\hline
\end{tabular}




\begin{tabular}{|l|l|l|l|l|l|l|l|r|}
\hline L1 & 3 & 23 & 3 & 23 & 7 & 54 & 13 & 100 \\
L2 & 3 & 18 & 3 & 18 & 11 & 65 & 17 & 100 \\
L1 \& L2 & 6 & 23 & 11 & 42 & 9 & 35 & 26 & 100 \\
\hline Total & 12 & 21 & 17 & 28 & 26 & 51 & 55 & 100 \\
\hline
\end{tabular}

\subsection{Semi-structured interviews}

31 Our interviews with six BELF users and five HR managers confirmed our quantitative results and allowed us to further explore the relationship between BELF and professional competence.

During the interviews, the users explained how they perceived their own experience of English in the workplace. Although the accounts reflected individual experiences, they enabled us to identify three BELF features which may be considered as central to professional competence. The first feature concerns the specialized function of English enabling users to conduct their professional activities. This function was particularly salient when the interviewees were asked to describe their jobs and then describe the function of English in their own professional context, i.e. the company they worked for and their own professional domain. The juxtaposition of questions on professional practice with questions on their own practice of English made it very clear that the professionals interviewed perceived language not as an isolated skill, lying outside their individual experience and "waiting to be acquired" but, rather, as a form of embedded practice enabling the participants to live through their own professional experiences. By "living" we mean that the interviewees showed that English concerned specialized, relational, or emotional dimensions of their professional lives. The specialized dimension of English emerged when the interviewees explained why English was necessary and what level was required. This dimension may be characterized as a body of knowledge directly acquired in English and was generally referred to as "technical concepts" or "technical terms" by the participants. One of the participants, a senior manager of finance who claimed that doing her job without English was "virtually impossible" since she was in charge of coordinating finance across various European subsidiaries, explained her job was based on both the acquisition and application of specialized knowledge:

Although it is almost impossible to become proficient with all legislations, we need solid background knowledge of the countries where we work. For example, tax systems may differ markedly from one country to another. Since we work in the medical sector, we are constantly confronted with different social policy systems. Some countries reimburse cochlear implants, others don't. (Interview of a senior Finance Manager)

The specialized dimension of English may also be described as a form of practice in which professionals use their field knowledge in order to deal with professional or specialized routines such as participating in technical meetings, reporting specific problems to the hierarchy or exchanging technical information via instant messaging. One of our interviewees, an Information Systems engineer working at Potain, a cranemanufacturer with subsidiaries in various parts of Europe, described email as a central medium in his professional activities. He uses emails in English "at least three times a day" for different purposes such as sending minutes of meetings, solving technical 
problems and exchanging complex information. He also claims that English is systematically used in documents conveying specialized information (e.g. PowerPoint slides, spreadsheets and diagrams) to other parts of the multinational company.

The relational dimension of English as professional practice was also found in all interviews since English obviously allows communication with business partners. During the interviews, this dimension was regularly interlinked with the emotional dimension since, although the interviewees admitted they felt generally comfortable in English, using the language regularly created tensions or frustrations. This was notably the case when the participants referred to their communication with other non-natives and their trouble acquiring intercultural knowledge and putting that knowledge into practice. One interviewee working at Mapi Research Trust, a worldwide non-profit organization, claimed that she had trouble dealing with the different national varieties of English and admitted that she would be "totally lost if [she] found [herself] alone with Indian speakers". Other nonnative varieties of English were also mentioned by the other participants such as Chinese English and Vietnamese English. In these cases, the participants admitted that although English was the lingua franca, the common language, the variety was never culturally neutral or linguistically clear but, on the contrary, caused regular language frictions. More particularly, emotional tensions were mentioned by the participants when they referred to different proficiency levels which may in turn generate inferiority complexes. The following quote is from an interview with a computer network engineer working for an MNC which recently expanded to Asia. The interviewee describes his experience of coping with different national accents and proficiency levels:

I find it easier to communicate with Vietnamese partners because after all, they make as many mistakes as we do! It is much harder with our Indian partners who are real native speakers with a very complicated accent. (Interview of a network engineer)

Our interviews with five HR managers from different MNCs focused on how they personally perceived competence in English and how they assessed that competence during the recruitment process. One of the striking features in this context was that the managers' conceptions of English was not that of a "foreign language" but, rather, that of a professional lingua franca that enables employees to deal with professional practice including actions and behavior.

Competence in English was entirely related to professional competence in that competence in English was dependent upon the job's exposure to international business and/or to the corporate organization. The HR manager from Vibratec, a French company specializing in acoustics measurements, gave us an overview of professional practice involving the use of English for various job types. As shown in Table 6, competence in English covers diverse fields including professional expertise in acoustics, business development, and accounting. In some situations, such as when "engineers and technicians" and "commercial engineers" work for an international client, competence in English entirely overlaps with professional competence in that all actions are performed in this language. These job types contrast with accounting jobs where English competence focuses on specific actions such as emailing clients. 
Table 6. - Systemic approach to competence in English at Vibratec.

\begin{tabular}{|l|l|l|l|l|}
\hline Job title & Field & Mode and channel & Tenor & Examples \\
\hline $\begin{array}{l}\text { Engineers, } \\
\text { technicians and } \\
\text { project } \\
\text { managers }\end{array}$ & $\begin{array}{l}\text { Acoustics } \\
\text { measurements, } \\
\text { management }\end{array}$ & $\begin{array}{l}\text { Written and spoken } \\
\text { Emails, PowerPoint slides, } \\
\text { technical reports, } \\
\text { problem solving on the } \\
\text { phone }\end{array}$ & $\begin{array}{l}\text { Client- } \\
\text { expevider, } \\
\text { expert-lay }\end{array}$ & $\begin{array}{l}\text { Diagnosing noise in } \\
\text { Athen's tramway }\end{array}$ \\
\hline $\begin{array}{l}\text { Commercial } \\
\text { engineers }\end{array}$ & $\begin{array}{l}\text { Business and } \\
\text { acoustics }\end{array}$ & $\begin{array}{l}\text { Written and spoken } \\
\text { Emails, PowerPoint slides, } \\
\text { quotes, negotiating in } \\
\text { meetings, telephoning }\end{array}$ & $\begin{array}{l}\text { provider, } \\
\text { expert-lay }\end{array}$ & $\begin{array}{l}\text { an industrial client, } \\
\text { developing } \\
\text { new business }\end{array}$ \\
\hline Accountants & $\begin{array}{l}\text { Accounting, } \\
\text { finance }\end{array}$ & $\begin{array}{l}\text { Essentially written } \\
\text { Emails to clients }\end{array}$ & $\begin{array}{l}\text { Client- } \\
\text { provider, } \\
\text { expert-lay }\end{array}$ & $\begin{array}{l}\text { Settling accounts } \\
\text { with client in } \\
\text { China }\end{array}$ \\
\hline
\end{tabular}

Overlapping English/professional competences were also found in other HR interviews, especially when the company comprised several international business units. Two other HR managers, one working at Intrum Justicia (a Swedish MNC specializing in payment services) and one from Serco (a British MNC specializing in services), explained that overlapping was total in "corporate functions", (that is, functions that were central to the MNC such as HR or IS), and partial or insignificant in more local functions.

When asked about what and how they evaluated proficiency levels among candidates, all HR managers naturally insisted that language assessment depended on professional competence and its exposure to international contacts. The managers interviewed were therefore rather reluctant to use standardized tests, favoring tailor-made, more or less formalized methodologies. All HR managers admitted looking at international professional experience and used the interview in English to confirm qualities such as self-confidence in English. For the jobs in which competence in English and professional competence overlapped completely or almost completely, the candidates would go through a set of interviews including some with line managers who assessed their professional expertise in English. Most HR managers said they had no formal tool such as assessment rubrics and assessed proficiency levels according to their own view of language competence in work performance. However, one HR manager did present us with a set of formal descriptors (see Table 7) comprising categories which he used systematically for all corporate positions.

Table 7. - Proficiency levels in English: assessment categories used at Intrum Justicia.

\begin{tabular}{|l|l|}
\hline Proficiency level & Description \\
\hline "Basic" & Enough English to retrieve information from the company's intranet. \\
\hline
\end{tabular}




\begin{tabular}{|l|l|}
\hline "Daily English" & $\begin{array}{l}\text { Critical for corporate-level positions. Successful candidates can write short } \\
\text { emails and 3-4 page documents in financial and legal English. }\end{array}$ \\
\hline "Specialist level" & $\begin{array}{l}\text { Successful candidates can write long and complex documents in legal and } \\
\text { financial English. }\end{array}$ \\
\hline
\end{tabular}

As with the BELF users, our interviews of HR managers showed that they were grappling with conflicting norms. Aware that the conformity to native English was generally useful but not commonly found among candidates, they were also conscious of the fact that non-native proficiency could be found among many candidates. Nonnative proficiency was described in pragmatic terms such as "being comfortable in conversations", "not being afraid to speak" or in linguistic terms such as "writing errorless emails". Non-native proficiency was also described in more precise terms. One HR manager admitted he sought managers who could "develop relationships" or "think" directly in English without "resorting to French". The HR manager from the acoustics company said she was looking for engineers or technicians who could deal with the whole work chain, i.e. "traveling abroad", "organizing acoustics measurements on site", and "draft reports and quotes" that would later be sent to potential clients.

\section{Discussion and conclusion}

Our study is clearly limited by the size of the samples but it is worth noting that the results tend to cohere into a fairly clear picture of English competence among French professionals and managers. Foreign languages are often the hidden or the forgotten factor in international management (Marschan-Piekkari, Welch \& Welch, 1999; Harzing, Köster \& Magner, 2011) but our study suggests that English forms an integral part professional competence. Our data indeed shows that language competence cannot be reduced to a set of functional skills enabling professionals to perform specific actions such as sending emails, writing reports, or participating in meetings. Rather, our study illustrates that English requires the broader term of "competency" defined by Kamar \& Syed (2012) as a deeply "embedded skill" (ibid.: 255) enabling professionals to act and behave within the framework of professional competence. In this framework, English competency embraces different forms of knowledge which may be referred to as "environmental", "domain-bound" and "routine-bound". Environmental knowledge is of the highest order and corresponds to the highest category of the International Standard Classification of Occupations or that of the French job classification system (Répertoire opérationnel des métiers et des emplois). The category may be defined as the knowledge of the general setting such as the type of sector or organization in which people work (industrial versus craft, public versus private institutions, MNCs versus SMEs). Domain-bound knowledge is one that has been acquired through formal training or education and typically relates to disciplinary and multi-disciplinary knowledge. Some examples from our study include mechanical engineering, accounting, or web programming. This form of knowledge comprises terminology, discursive practices which may sometimes be unique to a domain but also, as French scholar Mourlhon-Dallies (2008) suggests, professional reasoning (logiques professionnelles) which the author defines as the specific linguistic behaviors that have 
been acquired through disciplinary or professional training and which are then projected into business realities. The last category may be termed "routine-bound knowledge" as it refers to concrete, day-to-day type of actions which are performed by professionals in their jobs such as report writing, participating in meetings, or sending contracts by email. Routine-bound knowledge has been widely conceptualized in genre and register studies but represents only one facet of language competence in job performance.

41 In this framework, performing a job while using English means not only handling routine-level and specialized communication but also resorting to a form of professional culture based on types of knowledge of a higher orders (see Figure 1). The ability to handle this culture is clearly related to the concept of phronesis, a type of wisdom related to practical action, and may certainly be considered as what characterizes BELF as a specialized competency. In the context of our study, phronesis did indeed appear as a striking metaphor for the application of three types of knowledge within job performance, thus resulting in empowering norms which were sometimes formalized into ad hoc language assessment sheets used in HR contexts.

Figure 1. - BELF as a "specialized" competency.

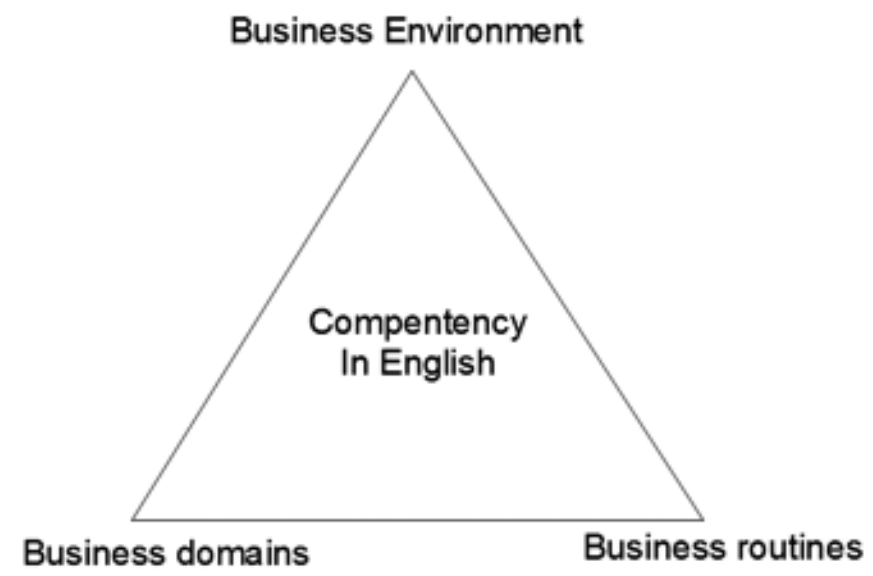

BIBLIOGRAPHY

ARnold Vanessa D. (1992), “The Communication Competencies Listed in Job Descriptions”, Business Communication Quarterly, 55(2), 15.

ATteWELl Paul (1990), “What Is Skill?”, Work and Occupations, 17(4), 422-48.

BARGIELA-CHIAPPINI Francesca \& HARRIS Ryan (1997), The Languages of Business: An International Perspective, Edinburgh: Edinburgh University Press.

BARGIELA-CHIAPPINI Francesca \& NICKERSON Catherine (1999), Writing Business: Genres, Media and Discourses, Harlow: Longman. 
BHATIA Vijay (1993), Analysing Genre: Language Use in Professional Settings, London: Routledge.

BHAtia Vijay (2017), “Analysing Discourse Variation in Professional Contexts”, V. Bhatia \& S. Bremner, The Routledge Handbook of Language and Professional Communication, Abington: Routledge, 31-77.

BHATiA Vijay (2002), "Professional Discourse: Towards a Multi-Dimensional Approach and Shared Practice", C. N. Candlin (ed.), Research and Practice in Professional Discourse, Hong Kong: Hong Kong University Press, 39-60.

BoYATIS Richard E. (1982), The Competent Manager, New York: Wiley.

CANDLIN Christopher N. (ed.) (2002), Research and Practice in Professional Discourse, Hong Kong: Hong Kong University Press.

CANDLIN Christopher N. \& SARANGI Srikant (eds) (2017), Handbook of Communication in Organisations and Professions, Berlin: De Gruyter Mouton.

CLOSE R. A. (1981), "English as a World Language and as a Mother Tongue", World Englishes, 1(1), 58.

CoGo Alissia \& DeWEy Martin (2012), Analysing English as a Lingua Franca: A Corpus-Driven Investigation, London: Continuum International Publishing Group.

DREW Paul \& HERITAGE John (1992), Talk at Work: Interaction in Institutional Settings, Cambridge: Cambridge University Press.

GIMENEZ Julio (2006), “Embedded Business Emails: Meeting New Demands in International Business Communication", English for Specific Purposes, 25, 154-72.

HALLIDAY Michael \& HASAN Ruqaiya (1976), Cohesion in English, London: Longman.

HARZING Anne-Will, KÖSTER Kathrin \& MAGNER Ulrike (2011), "Babel in Business: The Language Barrier and Its Solutions in the HQ-Subsidiary Relationship", Journal of World Business, 46(3), 27987.

HousE Julian (2012), “English as a Lingua Franca and Linguistic Diversity”, Journal of English as a Lingua Franca, 1(1), 173-5.

ISANI Shaeda (2004), "Compétence de culture professionnelle : définition, degrés et didactisation", ASp, 43-44, 5-21.

JACOBY Sally \& MCNAMARA Tim (1999), “Locating Competence”, English for Specific Purposes, 18(3), 213-41.

JENKINS Jennifer (2007), English as a Lingua Franca: Attitude and Identity, Oxford: Oxford University Press.

JenKINS Jennifer, Modiano Marko \& SEIDlHofer Barbara (2001), “Euro-English”, English Today, 17(4), 13-19.

KACHRU Braj B. (1981), “The Pragmatics of Non-Native Varieties of English”, L. E. Smith (ed.), English for Cross-Cultural Communication, New York: St. Martin's Press, 15-39.

KAMAR Robin \& SYED Jawad (2012), Human Resource Management in a Global Context: A Critical Approach, New York: Palgrave Macmillan.

KanKAANRANTA Anna (2006), “Hej Seppo, Could You Pls Comment on This? Internal Email Communication in Lingua Franca English in a Multinational Company", Business Communication Quarterly, 69, 216-25. 
KanKAANRANTA Anna \& Planken Brigitte (2010), “BELF Competence as Business Knowledge of Internationally Operating Business Professionals", Journal of Business Communication, 47(4), 380407.

KNAPP Karlfried \& MEIERKORD Christiane (2002), Lingua Franca Communication, Bern: Peter Lang. KoESTER Almut (2010), Workplace Discourse, London: Continuum International Publishing Group. LEMP (2015), Langues et employabilité. Analyse des besoins des employeurs français au regard des compétences en langues étrangères (Rapport d'enquêtes du projet LEMP), <www.ciep.fr/sites/ default/files/atoms/files/rapport-d-enquetes-lemp.pdf>.

Louhiala-SAlminen Leena (2002), “The Fly's Perspective: Discourse in the Daily Routine of a Business Manager", English for Specific Purposes, 21(3), 211-31.

LOUHIALA-SALMinEN Leena \& KANKAANRANTA Anna (2012), "Language as an Issue in International Internal Communication: English or Local language? If English, What English?", Public Relations Review, 38(2), 262-9.

Marschan-PiekKari Rebecca, Welch Denice E. \& Welch Lawrence S. (1999), “Adopting a Common Corporate Language: IHRM Implications”, International Journal of Human Resource Management, 10(3), 377-90.

MiLLoт Philippe (2017), "Inclusivity and Exclusivity in English as a Business Lingua Franca: The Expression of a Professional Voice in Email Communication”, English for Specific Purposes, 46, 59-71.

MOURLHON-DALliES Florence (2008), Enseigner une langue à des fins professionnelles, Paris: Didier.

NICKERSON Catherine (1999), "The Use of English in Electronic Mail in a Multinational Corporation”, F. Bargiela-Chiappini \& C. Nickerson (eds), Writing Business: Genres, Media and Discourses, Harlow: Longman, 35-56.

NICKERSON Catherine (2000), Playing the Corporate Language Game: An Investigation of the Genre and Discourse Strategies in English Used by Dutch Writers Working in Multinational Corporations, Amsterdam: Rodopi.

PoncinI Gina (2005), “Constructing an International Event in the Wine Industry: An Investigation of Emails in English and Italian”, P. Gillaerts \& M. Gotti (eds), Genre Variation in Business Letters, Berne: Peter Lang, 205-31.

PopPI Franca (2016), “From Business Letters to Emails: How Practitioners Can Shape Their Own Forms of Communication More Efficiently", G. Alessi \& G. Jacobs, The Ins and Outs of Business and Professional Discourse Research, London: Palgrave Macmillan, 272-94.

QUIRK Randolph, GREENBAUM Sidney, LEECH Geoffrey \& SVARTVIK Jan (1972), A Grammar of Contemporary English, New York: Longman Group.

REEVES Nigel \& WRIGHT Colin (1996), Linguistic Auditing: A Guide to Identifying Language Communication Needs in Corporations, Cleveland, Philadelphia, Adelaide: Multilingual Matters Ltd. Rouleau Linda \& BALogun Julia (2011), “Middle Managers, Strategic Sensemaking, and Discursive Competence", Journal of Management Studies, 48(5), 953-83.

SANDBERG Jorgen (2000), “Understanding Human Competence at Work: An Interpretative Approach", Academy of Management, 43, 9-25. 
SANDBERG Jorgen (2001), “Understanding Competence at Work”, Harvard Business Review, 79(3), 246.

SANDBERG Jorgen \& PinNington Ashly (2009), "Professional Competence as Ways of Being: An Existential Ontological Perspective", Journal of Management Studies, 46(7), 1138-70.

SARANGI Srikant \& ROBERTS Celia (eds) (1999), Talk, Work and Institutional Order: Discourse in Medical, Mediation and Management Settings, Berlin, New York: Mouton de Gruyter.

SAULIÈRE Jérôme (2013), “Les entreprises françaises malades de l'anglais", Huffington Post

(Les blogs), <https://www.huffingtonpost.fr/jerome-sauliere/anglais-entreprises-

francaises_b_3470643.html>.

SEIDLHOFER Barbara (2011), Understanding English as a Lingua Franca, Cambridge: Cambridge University Press.

SHAW Philip (2011), “Conditions for Success in Lingua Franca Interaction”, ASp, 60, 65-79.

TAYLOR Frederick Winslow (1911), Principles of Scientific Management, New York: Harper \& Brothers.

WeEKs Francis (1974), “Communication Competencies Listed in Job Descriptions”, Business

Communication Quarterly, 34(4), 22-37.

WENGER Etienne (1998), Communities of Practice: Learning, Meaning, and Identity, Cambridge: Cambridge University Press.

WozNIAK Séverine (2010), "Language Needs Analysis from a Perspective of International Professional Mobility: The Case of French Mountain Guides”, English for Specific Purposes, 29(4), 243-52.

ZARIFIAN Philippe (2004), Le modèle de la compétence, Paris : Éditions Liaisons.

\section{NOTES}

1. For further information on the topic, see the LEMP report (2015).

2. "Que faire lorsque l'on ne me dit plus comment faire?"

3. Official website: <www.monster.fr>.

4. Simply put, it is a qualitative research approach that investigates how people experience or think about something.

5. English proficiency, operational English, good English required, fluent English

6. Professional English, technical English

7. <www.orona-group.com/en/about-orona/business-group >.

\section{ABSTRACTS}

English has become an established lingua franca among French professionals who work at national and international levels. The language clearly empowers those who use it: it provides access to highly valued, international business situations, as well as to a growing number of jobs where English has become "a must" in the recruitment process. In this article, we present the 
results of a relatively small, but longitudinal study of English in the French workplace. Our study is based on 1) a quantitative analysis of recently published French job advertisements, 2) an online survey submitted to professionals from several professional backgrounds, and 3) semistructured interviews of French professionals who use English as a lingua franca. In line with previous studies and frameworks (Louhiala-Salminen, 2002; Bhatia, 2017), our study suggests that competence in English in the workplace cannot be reduced to a set of skills to be used regardless of the context, nor can it be seen as a form of knowledge lying outside professional domains. Rather, our findings tend to show that competence in English may be defined as a form of experience acquired through the exposure to specific professional situations. In these situations, discursive, terminological, and cultural practices are internalized by professionals and sometimes generate specialized language norms which directly suit the professionals' needs, especially at corporate level. Those norms are not only used in day-to-day practices but also tend to develop into more or less formal standards used in the recruitment process against which other non-native professionals are assessed. English competence in job performance therefore appears as a form of phronesis, or "pratical wisdom", in which the knowledge of specialized, international situations is used as a set of ad hoc frameworks which are sometimes formalized into pragmatic, corporate-bound standards.

L'anglais est désormais une lingua franca bien établie chez les professionnels en France, que ces derniers travaillent à un niveau international ou national. Cette langue leur confère une forme de pouvoir tel que l'accès à des situations internationales valorisantes mais, également, à des emplois pour lesquels l'anglais est devenu une obligation dans le processus de recrutement. Dans cet article, nous présentons une étude longitudinale de l'utilisation de l'anglais en contexte professionnel français. Cette étude se fonde sur 1) une analyse quantitative d'annonces d'emplois publiées récemment, 2) un sondage administré en ligne et 3) des entretiens semi-guidés avec des professionnels de profils variés. Dans la lignée des études précédentes (Louhiala-Salminen, 2002 ; Bhatia, 2017), notre étude suggère que la compétence en anglais professionnel ne saurait être réduit à un ensemble de savoir-faire utilisables quel que soit le contexte ni à des connaissances extérieures aux domaines professionnels. Nos résultats indiquent plutôt que la compétence en anglais peut être définie comme une forme d'expérience acquise à travers l'exposition à des situations professionnelles spécifiques. Dans ces situations, les pratiques discursives, terminologiques et culturelles sont internalisées par les professionnels eux-mêmes et elles génèrent des normes langagières qui répondent directement aux besoins des professionnels, notamment au niveau de l'entreprise. Ces normes sont non seulement utilisées dans les pratiques quotidiennes mais tendent également à être formalisées en critères d'évaluation plus ou moins formels et utilisées dans le processus de recrutement. La compétence en anglais dans l'évaluation de la performance professionnelle apparaît alors telle une forme de phronesis ou «sagesse pratique " dans laquelle la connaissance de situations spécialisées internationales est utilisée comme un ensemble de cadres ad hoc parfois formalisés en standards pragmatiques propre à chaque entreprise.

\section{INDEX}

Mots-clés: anglais comme lingua franca professionnelle, compétence professionnelle, compétence langagière spécialisée, approche phénoménographique

Keywords: Business English as a lingua franca, BELF, professional competence, specialized language competence, phenomenographic approach 


\section{AUTHOR}

\section{PHILIPPE MILLOT}

Philippe Millot wrote a doctoral thesis on English as a business lingua franca. He now works as a Senior Lecturer in English for specific purposes at the University of Lyon (France). His research mainly focuses on professional discourse analysis, English as a business lingua franca as well as corpus linguistics. He has published widely in these areas and some of his work is available in open access.

philippe.millot@univ-lyon3.fr 